\title{
Carrying capacity as a tool to design tourism policy: case study for the island of Rhodes
}

\author{
D. G. Prokopiou ${ }^{1}$, B. S. Tselentis ${ }^{1}$, G. Mavridoglou ${ }^{2} \&$ S. Zougla ${ }^{3}$ \\ ${ }^{1}$ Department of Maritime Studies, University of Piraeus, Greece \\ ${ }^{2}$ Technological Educational Institute of Peloponnesus, Greece \\ ${ }^{3}$ Scientific Researcher-Teacher, Rhodes, Greece
}

\begin{abstract}
The tourist industry is one of the most important economic activities in Greece. The country receives over 20 million visitors per year. In an era where tourism is one of the fastest growing sectors of the developing countries the competition with existing tourism destinations, such as Greece, will intensify. Greece has enjoyed increasing numbers and revenues from tourism due to the unique environment, both natural and man-made, making it a high profile tourist destination. However, it is already clear that the uncontrolled growth of the industry can bring serious environmental and social problems, leading to a decline in the quality of tourist product and services provided. Tourism development is related with environment and natural resources management. Carrying capacity indices is a tool for evaluation of the impacts caused from tourism policy. In previous studies we produced a model of carrying capacity evaluation. In this study we go one step further using the results of our analysis for the Greek island of Rhodes to design a sustainable tourism policy scenario.
\end{abstract}

Keywords: tourism policy, tourism carrying capacity, tourism development at Rhodes Greek Island.

\section{Basic principles in the $\mathbf{E} \mathbf{U}$ tourism policy}

After the Agreement of Lisbon, for the first time the European Union, recognized tourism as a major economic activity with a broadly positive impact on economic growth and employment in Europe and tried for an EU tourism policy.

Tourism is an increasingly important aspect in the life of European citizens who are traveling more and more, for private or professional reasons. Tourism, is 
an activity that is related to the cultural and natural heritage and contemporary cultures and traditions of the European Union as is supports economic growth with sustainable development and the ethical dimension. Tourism is also has important meaning to enhance Europe's image worldwide, as it allows you to view the values and promote the attractiveness of the European model, which is the result of centuries of cultural exchanges, linguistic diversity and creativity.

The quantitative objective of European policy is that Europe is the first tourist destination in the world and tourism is able to capitalize the wealth and economic diversity of the regions. Moreover, as mentioned in the treaty, tourism is an economic activity that can generate growth and employment in the EU, while contributes economic development and social integration. Particularly tourism supports economy in rural and mountain areas, coastal regions and islands, as remotes the structure of the local economies. Key challenges to achieving this goal are:

i. The opening of new tourist markets

ii. Adapting to demographic developments

iii. Addressing the effects of climate change on tourism product.

According to the Lisbon Agreement strengthening the competitiveness of the tourism sector should take into account the long term, competitiveness is closely linked to the sustainability of the development.

This last point leads to the need for an environmentally sustainable practices in the tourism industry. That policy that has been raised by scientists from the $60 \mathrm{~s}$. The concept of sustainable tourism requires the identification of adverse effects and the need for manage to achieve the objectives of sustainable development and implementation of these policies.

Previous years the concept of sustainable tourism was implemented tourism development policies of a region as opposed to the conventional tourism prevalent in recent decades. Sustainable tourism based on new forms of tourism, alternative or special, where tourist demand arising from small groups of tourists. Economic growth will result from greater economic value of each tourist and not on massive development of small economic value tourists.

A key gauge of sustainability of a region is the carrying capacity of the area. Carrying capacity is designated generally "the maximum number of people that can use a site without any unacceptable modification to the natural environment and without an unacceptable reduction in the quality of the experience acquired by tourists" (Mathieson and Wall [1]). This definition is generalized to use and socio-cultural and economic environment and according to the World Tourism Organization, carrying capacity is "the maximum number of people that can simultaneously visit a tourist destination, without causing damage to the natural, economic and socio-cultural environment, as well as an inadmissible negation of quality and guest satisfaction". The above definition refers only to the satisfaction of tourists and researchers have already expressed the view that the carrying capacity should be measured and, for the residents.

Eventually Getz [2] has identified the concept of carrying capacity in six subcategories (physical, economic, perceptual, social, ecological and political), 
each with different implications. The carrying capacity is one of the central framework within which such issues can be addressed locally (Lindberg et al. [3]).

The live cycle of a tourist product development has been described by Butler [4]. The carrying capacity of the model referred as the element that limits growth, and appears in the stage of economic stagnation of the tourist destination and is shown as a relatively static zone which controls the amount of growth in a particular environment (Lagos and Diakomanolakis [5]). The interface between the life cycle representing the tourism development and the carrying capacity is a dynamic process (Butler [6], Martin and Uysal [7]). Despite the unlimited growth to any destination is impossible, but the shape of growth can have cyclical form (Baum [8], Butler [9]). As suggested in the final stage of economic stagnation or even earlier, if imported significant new products or marketing systems, the life cycle of a tourist destination can begin again to show growth. Otherwise, there may be a drop (Tooman [10]).

Accordingly, the limit of development in model development of Butler is not based on the capacity of the destination and the "original" resources for tourism absorption, but the industry (activity) and ability. A key common theme is the idea of limits to tourist use and changes in the physical and social environment to be accepted (Butler [11, 12]). The bearing capacity acts as a tool bounding while TTC index stagnation.

\section{Measurement carrying capacity}

To measure the carrying capacity of an area made using sustainable development indicators. In a previous work (Prokopiou et al. [13]) proposed measurement model of the bearing capacity of a region based on natural resources data, environmentalists and tourism infrastructure and traffic data [14].

The model was used to characterize the islands of Greece. The model was based on the following indicators which evolved to meet comprehensive environmental and tourist data in relation to the coastal zone:

1. Indicator I1: Coverage of urban wastewater

2. Index I2: Legality buildings

3. Indicator I3: Noise

4. Index I4: Refuse coverage

5. Index I5: Use pesticides

6. Index I6: Do not over-pump seawater

7. Index I7: Adequate water supplies

8. Index I8: Drinking water

9. Index 19: Absence of fire

10. Indicator I10: Scrub

11. Indicator I11: Maintain landscape

12. Indicator I12: Sufficiency green

13. Indicator I13: Beds per kilometer beach

14. Indicator I14: Beds per square kilometer

15. Indicator I15: Beds per resident

16. Indicator I16: Blue flags per kilometer beach 
The first 12 indicators grouped into three major categories Index Soil Environment - Water.

\section{Island of Rhodes}

Rhodes is the largest of the Dodecanese Archipelagos islands in terms of both land area and population. According to the 2011 Census, the population was 115,490 and it is the fourth largest island of Greece. It covers an area of 1,390 sq. km and has $70 \mathrm{~km}$ of beaches.

The island of Rhodes is one of the major tourist destination in Greece. Tourist development of the island of Rhodes started in 50s in the southern part of the island, called the southern triangle. Tourism supply in Rhodes includes more than 130,000 beds which cover tourism demand with more than 2 million international tourist arrivals per year (Tables 1 and 2). The Rhodes environment, both natural and man-made as the cultural and historical heritage can sustain a polymorphic tourism product.

Table 1: Arrivals at Rhodes airport.

\begin{tabular}{|c|c|c|c|c|}
\hline \multirow{2}{*}{ Year } & \multicolumn{2}{|c|}{ International } & \multicolumn{2}{c|}{ Domestic } \\
\cline { 2 - 5 } & Arrivals & Departures & Arrivals & Departures \\
\hline 2009 & $1,321,806$ & $1,327,955$ & 407,960 & 418,717 \\
\hline 2010 & $1,416,991$ & $1,428,051$ & 364,260 & 372,306 \\
\hline 2011 & $1,717,477$ & $1,737,505$ & 332,505 & 343,958 \\
\hline 2012 & $1,593,298$ & $1,606,937$ & 294,635 & 305,532 \\
\hline 2013 & $1,781,768$ & & & \\
\hline
\end{tabular}

Table 2: Cruise passenger arrivals.

\begin{tabular}{|c|c|c|}
\hline Year & Arrivals (Ships) & Arrivals (Passengers) \\
\hline 2010 & 536 & 565,786 \\
\hline 2011 & 526 & 588,171 \\
\hline 2012 & 448 & 472,308 \\
\hline 2013 & 373 & 409,991 \\
\hline
\end{tabular}

It is noteworthy that the population of Rhodes has increased considerably during the period of 1950-2011 representing a rise more than $70 \%$. The increase of the population is considerably higher than the national average and has been associated to the increase in tourism especially after the 1970s in the north part of the island. In contrast the southern part of the island has retained its rural character and has not participated in the development of mass tourism in the way the northeastern and north-western regions of the island have.

Apart from tourism in GDP of the island should be calculated as income from agricultural products, SMEs and services. Agricultural land has, on the whole, remained unchanged $(330,000$ sq. $\mathrm{km}$.), whereas small manufacturing units are 
mainly oriented towards agricultural products, juices-soft drinks-drinks, olive oil presses, ceramics, pottery, furniture and goldsmiths. Finally as far as tertiary production is concerned, Rhodes is the administrative center for all the Dodecanese islands. Employment in the primary and secondary production level has dropped whereas there is an increase in the tertiary level, confirming both the national trend as well as the increase in the tourist trade for the area, during the 1980s.

Focusing on the resources and infrastructure of the island, factors measured at the carrying capacity assessment model we must:

i. Water, increased demand during the summer months has been a serious problem for the island. The need to provide satisfactory water quality remains a pressing issue both to local citizens as well as visitors during summer.

ii. Urban waste management (solid and liquid) is characterized by the lack of efficiency and environmental protection. Only the large urban centers fulfill the basic requirements of modern waste management installations.

iii. Electrical consumption has increase over recent years. The surge in consumption during the summer months is also highlighted. Taking into account that the power generation plant at Soroni is powered by heavy duty oil, it is not surprising that both costs and environmental impacts are high for the island.

iv. Rhodes is a bad practice example of tourist planning. The first areas have been developed on basis at plan were Ixia and Faliraki. The building method in tourist areas and villages has brought alteration in traditional architectural model. The illegally building construction in tourist areas in the island can be distributed to the following categories:

a. Illegally constructed hotels,

b. Illegally used buildings as hotels, and

c. Other illegally buildings in the seashore.

The following activities can be identified as important pressures on coastal ecosystems:

1. Permanent exploitation of tourist industry

2. Garbage is dumped at sea

3. The cleaning and flattering of coasts carried out with the use of machines

4. Traffic

5. The coastal cereals and vegetables cultivations

6. The sand exploitation

7. Soil erosion

8. The model of tourism used in practice imposes the existence of night clubs, the operation of which takes place after formation providing in certain areas. The policy of specific working hours aims to the particularization of every single region without, however, always protecting the citizens from noise.

Tables 3 and 4 present the total score, calculated as the arithmetic mean, and the standard deviation by environmental variable for whole the island of Rhodes. High score is presenting to the following variables: legality of buildings, protection of noise nuisance, garbage management, protection of pesticides using, 
over pumping in sea waters, sufficient quantity of water resources, sufficient quality of drinking and adequacy of green areas, the mean score for these variables are between $80 \%-100 \%$.

Table 3: Environmental indicators per municipality.

\begin{tabular}{|c|c|c|c|c|c|c|c|}
\hline Municipality & $\begin{array}{c}\text { Urban } \\
\text { waste } \\
\text { manage- } \\
\text { ment }\end{array}$ & $\begin{array}{c}\text { Legality of } \\
\text { buildings }\end{array}$ & $\begin{array}{c}\text { Protection of } \\
\text { noise } \\
\text { nuisance }\end{array}$ & $\begin{array}{c}\text { Garbage } \\
\text { management }\end{array}$ & $\begin{array}{c}\text { Protection } \\
\text { of pesticide } \\
\text { use }\end{array}$ & $\begin{array}{c}\text { Over } \\
\text { pumping in } \\
\text { sea waters }\end{array}$ & $\begin{array}{c}\text { Sufficient } \\
\text { quantity of } \\
\text { water } \\
\text { resources }\end{array}$ \\
\hline Rhodes Town & 100.0 & 100.0 & 50.0 & 80.0 & 100.0 & 100.0 & 100.0 \\
\hline Arhaggelos & 0.0 & 100.0 & 100.0 & 80.0 & 100.0 & 100.0 & 100.0 \\
\hline Attaxiros & 30.0 & 100.0 & 100.0 & 80.0 & 100.0 & 100.0 & 100.0 \\
\hline Afandou & 0.0 & 100.0 & 100.0 & 80.0 & 100.0 & 100.0 & 100.0 \\
\hline Ialysos & 65.0 & 100.0 & 0.0 & 80.0 & 0.0 & 100.0 & 100.0 \\
\hline Kallithea & 20.0 & 100.0 & 50.0 & 80.0 & 100.0 & 100.0 & 100.0 \\
\hline Kamiros & 20.0 & 100.0 & 100.0 & 80.0 & 100.0 & 100.0 & 100.0 \\
\hline Lindos & 60.0 & 100.0 & 100.0 & 80.0 & 0.0 & 100.0 & 100.0 \\
\hline South Rhodes & 0.0 & 100.0 & 100.0 & 80.0 & 100.0 & 100.0 & 100.0 \\
\hline Petaloudes & 60.0 & 100.0 & 100.0 & 80.0 & 100.0 & 100.0 & 100.0 \\
\hline
\end{tabular}

Table 4: Environmental indicators per municipality (part 2).

\begin{tabular}{|c|c|c|c|c|c|c|c|}
\hline Municipality & $\begin{array}{c}\text { Protection } \\
\text { of fire } \\
\text { incidents }\end{array}$ & $\begin{array}{c}\text { Forest } \\
\text { clearance }\end{array}$ & $\begin{array}{c}\text { Conservation } \\
\text { of the } \\
\text { landscape }\end{array}$ & $\begin{array}{c}\text { Adequacy } \\
\text { of green } \\
\text { areas }\end{array}$ & $\begin{array}{c}\text { Beds/km } \\
\text { of beach }\end{array}$ & Beds/km² & $\begin{array}{c}\text { Beds per } \\
\text { inhabitant }\end{array}$ \\
\hline Rhodes Town & 100.0 & 100.0 & 80.0 & 100.0 & 678.23 & 2549.6 & 850.7 \\
\hline Arhaggelos & 100.0 & 100.0 & 0.0 & 0.0 & 186.44 & 186.4 & 16.32 \\
\hline Attaxiros & 0.0 & 100.0 & 100.0 & 100.0 & 34.35 & 34.35 & 0.34 \\
\hline Afandou & 100.0 & 0.0 & 50.0 & 100.0 & 1375.4 & 1375.4 & 223.77 \\
\hline Ialysos & 100.0 & 0.0 & 50.0 & 100.0 & 3368.3 & 3368.3 & 1068.9 \\
\hline Kallithea & 100.0 & 0.0 & 50.0 & 100.0 & 3911.08 & 3911 & 231.64 \\
\hline Kamiros & 0.0 & 100.0 & 100.0 & 100.0 & 8.0 & 8.0 & 1.02 \\
\hline Lindos & 0.0 & 100.0 & 80.0 & 0.0 & 1188.3 & 1188.3 & 73.73 \\
\hline South Rhodes & 100.0 & 0.0 & 80.0 & 100.0 & 105.1 & 105.1 & 12.9 \\
\hline Petaloudes & 0.0 & 0.0 & 100.0 & 100.0 & 258.4 & 258.4 & 49.28 \\
\hline
\end{tabular}


The management of the urban waste with $35.50 \%$ indicates that the urban waste management has lack of efficiency, due the many incidences of forest clearance the correspond indicator takes the low score $60.0 \%$. The non-effective protection against fires in forests are serious threat for the environment, so the score to correspond variable, is only $60.0 \%$.

According to Table 5, infrastructure indicators I13 to I15 for the island of Rhodes are in low level, this score indicates large burden of the environment.

Table 5: Environmental indicators for the island of Rhodes. Mean score and standard deviation by variable.

\begin{tabular}{|l|c|c|}
\hline \multicolumn{1}{|c|}{ Variable Name } & Mean & St Dev \\
\hline Urban waste management & 35.5 & 34.2 \\
\hline Legality of buildings & 100 & 0 \\
\hline Protection of noise nuisance & 80 & 35 \\
\hline Garbage management & 80 & 0 \\
\hline Protection of pesticide use & 80 & 42.2 \\
\hline Over pumping in sea waters & 100 & 0 \\
\hline Sufficient quantity of water resources & 100 & 0 \\
\hline Sufficient quality of drinking water & 100 & 0 \\
\hline Protection of fire incidents & 60 & 51.6 \\
\hline Forest clearance & 50 & 52.7 \\
\hline Conservation of the landscape & 69 & 31.8 \\
\hline Adequacy of green areas & 80 & 42.2 \\
\hline Beds per kilometre of beach & 62.39 & 39.29 \\
\hline Beds per square kilometer & 36.68 & 43.15 \\
\hline Beds per inhabitants & 59.52 & 39.85 \\
\hline Blue flags per kilometre of beach & 11.54 & 28.03 \\
\hline
\end{tabular}

\section{Results}

Environmental indicators by municipality are presented in Tables 3 and 4 according the results for the urban waste management Arhagelos, Afandou, Kallithea, Kamiros and Notia Rodos are the municipalities with the major pressures. There is protection to environment against illegal buildings, and the level of protection against the noise. Garbage management is cohered at all the municipalities with places of sanitary burial. Protection against pesticide use is implemented in all the municipalities except Ialysos and Lindos. There are not any incidents from over pumping in sea waters. The quantity of water resources is adequate as also the quality of drinking water. There are no fire incidents except Lindos Ataxiros and Petaludes. Incidents of forest clearance happened in tourist area as Afandoy, Ialysos Kallithea and southern Rhodes. 
Finally, for the entire island the management of the urban waste with $35.50 \%$ indicates that the urban waste management has lack of efficiency, due the many incidences of forest clearance the correspond indicator takes the low score $60.0 \%$. The non-effective protection against fires in forests is serious threat for the environment, so the score to correspond variable, is only $60.0 \%$.

\section{Discussion}

The existing tourism policy in Greece is mainly based on facilitation of private investment and construction.

To the key points of this policy, proposals that do not take into account the carrying capacity of each area indicators can be founded, including:

1. Introduce mining activities within the areas designated "tourism priorities" that affect the natural environment.

2. Increase of the building factor in off-plan areas from $200 \mathrm{sq} \mathrm{m}$ to $800 \mathrm{sq} \mathrm{m}$, which allows the construction of colossal units beside the foreshore.

3. It allows the granting of rights to use the foreshore, beach, contiguous or adjacent sea space in front of complex tourist accommodation or tourist accommodation 5 or 4 stars, for the construction or retrofitting of existing platforms, to service boats and swimmers. There are reports on the environmental conditions and again while private mooring structures proliferate.

4. The elimination of step prior approval architectural design and the plot or land suitability for hotel accommodation.

5. Fast speed control of documents and within fifty days to grant E.S.L. but take care of the proper staffing of the supervisory authorities, resulting in insufficient controls.

6. Allow the construction or retrofitting of existing platforms, serving vessels and swimmers.

7. Defined specifications for wine tourism and medical/healing. It does not set the operating signal of medical tourism.

These policies in the case of Rhodes where "clasical" tourist development has reached, according to the carrying capacity assessment model, the limits it can't lead to forms of sustainable development.

It is the time for the island of Rhodes to design a new tourism policy and introduce new tourist products, such as conference tourism, alternative tourism and cruise tourism.

Table 6: Indexes and total score for the island of Rhodes.

\begin{tabular}{|l|c|c|}
\hline & Mean & St Dev \\
\hline Ground Index & 57.75 & 17.1 \\
\hline Water Index & 98.00 & 4.22 \\
\hline Nature Index & 75.13 & 10.35 \\
\hline Total Score & 59.97 & 11.08 \\
\hline
\end{tabular}


The key points for this change are:

1. Tourist development indicators for Rhodes lead us to conclude that the tourism industry should aim at extending the tourist season to include more months, attain occupancy well over $50 \%$ for April, October, and probably more visitors with varied interests and expectations of the island, organization for the protection and development of environmentally sensitive areas. Extension of tourism services for the winter season months by developing and marketing novel tourist activities particular for the island (mountaineering, cultural events, conferences, etc.).

2. Due to the increased tourism demand, it is suggested that all the areas with environmental interests must be protected by a special organization that, doesn't exist for the time in. Nature 2000 Network areas are a step in the right direction, but must be supported with effective management schemes.

3. Completion of urban waste treatment plants and network, appropriate garbage handling (urban garbage treatment - olive oil press residuals management), restriction of illegal buildings at cities and coasts, control of hotel's urban waste management systems.

4. The concept of linking visitors with culture, nature and the environment in a harmonious way is not a new idea, but is now viewed on a global scale.

5. Long-term, successful community involvement has preserved many popular rural tourist destinations such as the wine regions of Europe and the United States, many rural communities have acted on instinct, rather than governmental directives or support, and usually with enough individual investment to achieve results.

6. Alternative tourist development is conceptually related to sustainable development includes approaches to deal with development and economic options, to prevent environmental damage and to involve public and stakeholders in decision-making processes. It is proposed that serious efforts have to make in the direction of formulating viable policies and developing tools for effective implementation and control, as till now alternative tourism is not yet massively developed in Rhodes. xiii. Tourism industry of the island must be extended by supporting winter time charter flights.

7. Planning is conceptually related to sustainable development. It includes approaches to deal with development and economic options, to prevent environmental damage and to involve public and stakeholders in decisionmaking processes.

\section{References}

[1] Mathieson, A. and Wall, G., Tourism: economic, physical and social impact. Longman Scientific and Technical. New York. 1982.

[2] Getz, D. Capacity to absorb tourism: Concepts and implications for strategic planning Annals of Tourism Research Vol. 10, (2), pp. 239-263, 1983.

[3] Lindberg, K., S. McCool, and G. Stankey, Rethinking Carrying Capacity. Annals of Tourism Research 24:461-465, 1997. 
[4] Butler, R.W. The concept of tourism area cycle of evolution: implications for management of resources Canadian Geographer 24(1): pp. 5-12, 1980.

[5] Lagos, D. and Diakomanolakis, M., Carrying capacity Tourism Development for Island of Kos. Proceedings of ERSA Conference. Panteio University, Athens, 2011. Online to: https://plandevel.web.auth.gr/ ERSA_GR_CONF_2012.

[6] Butler, R. Modelling Tourism Development: Evolution, Growth and Decline. Tourism, Development and Growth: The Challenge of Sustainability, eds S. Wahab and J. Pigram. Routledge: London, pp. 109125, 1997.

[7] Martin, B. S., and Uysal, M., An Examination of Relationship Between Carrying Capacity and the Tourism Life Cycle: Management and Policy Implications. Journal of Environmental Management 31:327-333, 1990.

[8] Baum T., Taking the Exit Route: Extending the Tourism Area Life Cycle Model, Current Issues in Tourism, Vol. 1 (2), pp. 167-175, 1998.

[9] Butler, R., The Tourism Area Life Cycle in the Twenty-First Century. A Companion to Tourism, A. Lew, eds M. Hall and A. Williams. Oxford: Blackwell, pp. 159-169, 2004.

[10] Tooman, L., Applications of the Life-Cycle Model in Tourism. Annals of Tourism Research 24:214-234, 1997.

[11] Butler, R., The Concept of Carrying Capacity for Tourism Destinations: Dead or Merely Buried? Progress in Tourism and Hospitality Research 2(34): pp. 283-293, 1996.

[12] Butler, R., Sustainable Tourism: A State-of-the-Art Review. Tourism Geographies 1:7-25, 1999.

[13] Prokopiou, D.G, Tselentis, B.S, Mavridoglou, G., Prototype model of carrying capacity in tourism: the implementations for the island of Rhodes, 2nd Annual international interdisciplinary conference AIIC 2014, Ponta Delgada Azores, Portugal.

[14] Garrigós-Simón F., Narangajavana Y. \& Palacios-Marqués D., Carrying capacity in the tourism industry: a case study of Hengistbury Head, Tourism Management, vol 25 (2), pp. 275-288, 2004. 